\title{
Profile of Intuition of Male Student Mathematics Education in Mathematics Problem Solving
}

\author{
$1^{\text {st a,b }}$ Arwanto \\ ${ }^{a}$ Universitas Negeri Surabaya \\ Surabaya, Indonesia \\ ${ }^{b}$ Universitas Muhammadiyah Cirebon, \\ Cirebon, Indonesia \\ adearwan49@gmail.com
}

\author{
$2^{\text {nd }}$ I Ketut Budayasa \\ Universitas Negeri Surabaya \\ Surabaya ,Indonesia \\ iketutbudayasa@yahoo.com
}

\author{
$3^{\text {rd }}$ Mega Teguh Budiarto \\ Universitas Negeri Surabaya \\ Surabaya, Indonesia \\ megatbudiarto@yahoo.com
}

\begin{abstract}
This research is qualitative research, aimed to find out the profile of male students' intuition of mathematics education in solving math problems. Methods of data collection with the provision of mathematical problem solving using Polya stages, then conducted interviews on the subject in depth. In the interview process whether the male student's intuition profile of mathematics in the problem-solving stage has an impact on the subject or otherwise does not affect his mathematical intuition. The issue of the research is male students of Mathematics Education Student of the Muhammadiyah University of Cirebon. Research subjects amounted to one male student. The results showed the application of intuition profile of male students of mathematics education in solving mathematical problems is: The effect of the subject by doing mathematical story problem is; In solving mathematical issues not using his mathematical intuition, in making mathematics problem-solving plan of the subject using direct intuition, in implementing mathematics problem-solving plan not using mathematics. And in checking back the troubleshooting steps, the subject checked again by checking according to the stage.
\end{abstract}

\section{Keywords - Intuition, Mathematical problem solving}

\section{INTRODUCTION (HEADING 1)}

Fishbein says that the intuitive is a mental process (cognition) that has specific characteristics [1,2]. According to him, the intuitive role is seen as a role of cognitive type. The knowledge built through this mental process is called intuitive knowledge. On the other hand, intuitive is defined as immediate cognition and has characteristics in between; selfevident and immediacy. Tthe subject sees their statement immediately accepted without the need for extrinsic justification by formal evidence or empirical support), intrinsic certainty, perseverance, (commonly excluded as unacceptable) globality, (intuitively offering a global view of unity. In contrast to explicit, analytical and discursive thinking) extra-polativaness, (indirectly exploring), implicitness, (intuitive processes are generally unconscious, and the person who is aware only of the final product) and theory status, Intuitive is a theory, never just a skill or a perception.

Winerman in Nicholas 2010 supports the above statement by saying that "Intuition as the act or process of coming to direct knowledge or certainty with little reasoning or inferring"[3]. In other words that intuitive is the act or process of acquiring knowledge directly or is believed to be right with a guess or a little reasoning. Thus the intuitive role has greater potential that can provide the ease in understanding and simultaneously guiding in verifying the truth when faced with problems that can not be reached the mind or the senses.

Fischbein reveals that "intuitive is a tool used to predict a thought/theory and is very useful for finding the right strategy[4] when facing or are doing specific tasks (including when meeting and seeing the approach in solving mathematical problems). Winerman's statement supports the above opinion (in Nicholas, 2010: 3 that "Intuition as the act or process of coming to direct knowledge or certainly with little reasoning or inferring" in other words that intuition is an act or process of acquiring knowledge directly or is believed to be sure True to the supposition or a little reasoning, so intuition has greater potential that can provide the ease in understanding and simultaneously guiding in verifying the truth when faced with problems that can not be reached by reason or senses[3]. Some of the above understanding illustrates that intuition is a cognitive or mental process at the time of understanding information in the form of capturing, exposing or expressing ideas or knowledge based on feeling or feelings of subconscious and mixed with the knowledge and previous experience that is immediate, immediate, Automatically (its occurrence occurs so unnoticed) without thinking about it (Muniri 2010).

\section{METHODS}

This research is descriptive qualitative study aims to know the intuitive role of the student of mathematics education in solving the problem about mathematics story (basic mathematics). This research was conducted at the Muhammadiyah University of Cirebon. Subjects of this study amounted to male students of mathematics education. 
In this research data are (1) data of problem-solving test of math story, (2) written answer from the problem-solving analysis and (3) then data of interview result to the research subject. The data of problem-solving test is used to determine the subject of the research, while the data about the interview result is used to describe the intuitive profile of the mathematics education student in solving the problem of mathematics story. The analysis of data conducted by the researchers by using Polya steps, among others: (1) transcribing verbal data that have been collected, (2) review all available data, (3) perform data reduction, (4) data exposure, (5) analyze the students' intuitive role in solving the story problem (basic mathematics).

\section{RESULT AND DISCUSSION}

A candy company has three warehouse goods in each city. Each warehouse stores 100 boxes of candy. One table consists of 15 large packs. A large package contains 12 small bags. The price of a small container of candy is Rp. 7.500, -. Of each warehouse, the company set aside $25 \%$ of the sale of candy to pay employee salaries, $20 \%$ for capital and raw materials, and $10 \%$ for warehouse operational costs. What is the net profit of the candy company?

The result of interview the subject of mathematics subject in solving mathematical problems using polya step, then get the intuition profile as follows:

\section{A. Understand the Problem}

The subject receives intuition as a direct cognition accepted as an individual feeling of the subject without requiring further checking and verification processes. It is self-evident, a self-evident statement. One of the answers that came up during the interview was: "There are three warehouses in each city. Each warehouse stores 100 boxes of candy. One box consists of 15 packs. A large pack contains 12 small packs. Price of one pack of candy Rp.7.500. Company set aside $25 \%$ for $20 \%$ salary for capital and raw materials $10 \%$ for operational usually. And he says it is easy to understand ".

Analysis of intuition data subject of mathematics education students in solving mathematical problems at the stage of understanding mathematical problems using extrapolativeness intuition is an intuition that describes the subject to see the interpretation, decisions, or conclusions of certain mathematical problems based on insufficient information or data. This is proved that in understanding the problem the subject says that there is only proven by itself without requiring further examination. This indicates that the subject when interviewed by the researcher gives a direct answer, among which is subjects view specific interpretations, decisions or conclusions based on insufficient information or data. (Extrapolativeness). "The subject says to make illustrations first. To remember the formula that is forgotten by how to search first using the illustration drawing".

\section{B. Plan for completion}

Analysis of the intuitive data of the subject of mathematics education students in solving mathematical problems at the stage of making a mathematical problem solving plan, the subject using Coerciveness intuition, the intuition that illustrates that the subject tends to impose the truth of the statement, representation or interpretation. The subject is difficult to accept the correctness of reports, descriptions or alternative analysis related to his story. And also the subject of making a solution plan made globally is look at the whole in making the answer plan that will be in use.

Subjects tend to impose the correctness of statements, representations or interpretations. The subject is difficult to accept the truth of the report, description or analysis of alternatives related to his story (Coerciveness). "For example in planning a planned settlement using the concept of algebra. When the subject sees from this question includes the question of social arithmetic using the concept of algebraic operations ".Subjects globally object concept, or knowledge of the parts (Globality). The characteristics are three warehouses, each storing 100 boxes of candy, a box consisting of 15 large packages, a large pack of 12 small bags.

A statement, a representation, or an interpretation is considered an exact subject by itself. The subject feels no need to show / formally prove the truth of that statement, image, or interpretation. The report is clear to the student (Self-evident.) The subject draws in a drawing way there are three warehouses, each storeroom stores 100 boxes of candy, a table consisting of 15 large packs, a large bag of 12 small packages.

\section{Carry out a Settlement}

Analysis of the intuitive data of the subject of mathematics education students in solving mathematical problems at the stage of implementing mathematical problem solving, the subject uses Coerciveness intuition, the intuition that illustrates that the subject tends to impose the truth of the statement, representation or interpretation. The subject is difficult to accept the correctness of reports, descriptions or alternative analysis related to his story.

It is proved that subject considers the statement, its representation, or its interpretation, a certainty. There is no need for external support (formal or empirical to obtain it). (Intrinsic certainty). Results of candy sales (from 1

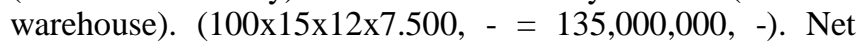
profit $(\%)=100-25-20-10=45$. Profit from 3 warehouses. 3 x 45/100 x 135.000.000, - = 182.250.000, - The subject said from the problem it already appears if there is a pattern in the form of al Jabar, so the operation is clear, so one warehouse profit 135 million. Subjects tend to impose the truth of statements, representations or interpretations. The subject is difficult to accept the truth of the statement, representation or interpretation of alternatives related to his statement (Coerciveness). The subject says: I think it is clear, that this uses the algebraic formula, because of social arithmetic. That profit from 1 warehouse pack. Rp 182,250,000, -

\section{Checking Answer}

Data analysis of the subject intuition of mathematics education students in solving mathematical problems at the stage of re-examining the answers to mathematical problems, subjects using Coerciveness intuition, the intuition that illustrates that subjects tend to impose the truth of statements, representations or interpretations. The subject is difficult to 
accept the correctness of reports, descriptions or alternative analysis related to the story.

It is proved that the subject in re-examining the problem answer the subject said I checked back in my own way whether the problem is correct or still wrong and the subject considers the statement, its representation, or its interpretation, a certainty. There is no need for external support (formal or empirical to obtain it). (Intrinsic certainty). Results of candy sales (from 1 warehouse). $(100 \times 15 \times 12 \times 7.500,-=135,000,000,-)$ Net profit $(\%)=100$ $25-20-10=45$. The advantages of 3 warehouses $3 \times 45 / 100$. $x$ 135 million, - $=182,250,000$, -Subjects tend to impose the truth of statements, representations or interpretations. The subject is difficult to accept the truth of the statement, representation or interpretation of alternatives related to his statement (Coerciveness). The subject said that I repeated answering and checking if something went wrong.

\section{CONCLUSION}

Based on data analysis and discussion, it can be concluded that the results of research indicate the role of intuitive mathematics education students in solving the problem of basic mathematics stories as follows: Subjects of male students of mathematics education that is a) Understanding the problem: the subject received intuition As direct cognition is accepted as the individual feeling of the subject without the need for further checking and verification processes. It is selfevident, a self-evident statement. Subjects view specific interpretations, decisions or conclusions based on insufficient information or data. (Extrapolativeness). B). Planning a settlement: Subjects tend to impose the truth of statements, representations or interpretations, the subject is difficult to accept the fact of the report, representation or interpretation of alternatives related to his report (Coerciveness). Subjects globally object concept, or knowledge of the parts (Globality). A statement, a representation, or an interpretation is considered a right matter by itself. The subject feels no need to show / formally prove the truth of that statement, image, or interpretation. The statement is clear to him. (Self-evident). C). Implement the settlement: The subject considers the statement, its representation, or its interpretation, a certainty, there is no need for external support (formal or empirical to obtain it). (Intrinsic certainty). Subjects tend to impose the truth of statements, representations or interpretations. The subject is difficult to accept the fact of the statement, representation or interpretation of alternatives related to his statement (Coerciveness). And d). Checking Answer: The subject considers the statement, its representation, or its interpretation, a certainty, there is no need for external support (formal or empirical to obtain it). (Intrinsic certainty).

\section{REFERENCES}

[1] Fischbein, E., 1983. “Intuitional and Analytical Thinking in Mathematic Educational". International Reviews on Mathematical Educational 15, 2 , $68-74$.

[2] Fischbein, E., 1999. " Intuitions and Schemata in Mathematical Reasoning" Educational Studies in Mathematics. 38,11-50.
[3] Nicholas, Paul K. 2010. Trends Concerning Four Misconceptions in Student Intuitively Based Probabilistic Reasoning Sourced in The Heuristic of representativeness. A. Disease in The Graduate School of The University of Alabama: Tuscaloosa Alabama.

[4] Fischbein, E., 1987. Intuition in Science and Mathematics: An Educational Approach. Dordrecht: Kluwer Academic Publisher.

[5] Muniri. 2010. Menumbuhkan Intuisi Siswa dalam Menghadapai Permasalahan Matematika (Makalah disampaikan dalam seminar regional tanggal 26 desember 2010, di STAIN Tulungagung)

[6] Nicholas, Paul K. 2010. Trends Concerning Four Misconceptions in Student Intuitively Based Probalistic Reasoning Sourced in The Heuristic of Representativeness. A Dissertation in The Graduate School of The University of Alabama: Tuscaloosa Alabama. 